\title{
THE NEXUS OF IMMIGRATION AND ECONOMIC CONDITIONS IN AUSTRALIA
}

\author{
Burcu Ozcan \\ Firat University • Elazig, Turkey
}

\section{ABSTRACT}

In this study, we aim to analyze the causal linkages between immigration and economic conditions - unemployment and per capita income- in Australia over the period of 1966-2013 by using causality tests developed by Toda and Yamamoto (1995) and Hacker-Hatemi-J (2006). The results support one-way causal relationships running from both unemployment and per capita income to immigration. However, immigrants do not have a significant impact on the economic conditions of Australia. On the contrary, the high level of income and the low unemployment rate are the pulling factors of immigrants into Australia. Based on these results, some crucial policy implications would be suggested.

Keywords: immigration, income, unemployment, causality, Australia

\section{INTRODUCTION}

Immigration seems to be more than a simple labor supply shock because it may induce efficient specialization in the labor market by differentiating skill levels and causing more competition (Peri, 2008). There are many different economic, political and social reasons for immigration such as war and political pressure, causing people to leave their home countries and to migrate into other nations that are wealthier and safer (Troshchenkov, 2011). Besides, declining transportation and information costs, as well as widening income differences between developing and developed countries along with accelerating population growth rates in developing countries are the main factors of immigration (Jean \& Jimenez, 2011).

Based on escalating trends in immigration waves worldwide, scholars from different disciplines have started to analyze the reasons and the results of immigration for various countries. In particular, as a population influx, immigration has led many economists to develop models designed to measure its social and economic impacts on receiving countries' economies (Aydemir \& Borjas, 2006). However, economic theory cannot provide a definite conclusion for predicting the effects of immigration, in particular on the labor market of the host country (Fromentin, 2013).

In this regard, some scholars (see Borjas, 1994; Boddvarsson, 2008; Damette 
\& Fromentin, 2013; Troshchenkov, 2011) assert that immigration has a little or no adverse impact on native employment opportunities. For instance, Jean and Jimenez (2011) argue that irrespective of their skill levels, new immigrants generate additional product demand and thereby raise profitability in the short-run and the capital stock in the long-run, with a positive impact on the demand for all types of labor. Additionally, many OECD countries see immigration as a potential solution to compensate for their labor shortages against their aging population problems (Boubtane et al., 2013). Alternatively, there is also a negative view highlighting that immigrants steal native labors' jobs, increase the unemployment level, depress the wage rates and financially strain the welfare systems in the receiving country as they are mostly unskilled (Feridun, 2007; Gross, 2004, Pope \& Withers, 1993).

Based on the contrasting ideas mentioned above, economic theory indicates that two competing effects (supply-side effects versus demand-side effects) could explain the impact of immigration on the labor market of a host country (see Feridun, 2004, 2005, 2007; Fromentin, 2013; Latif, 2015).Supply-side effects highlight the presence of substitutability or complementarity between native and foreign labors. In the case of substitution, there is an increasing competition between citizens and immigrants, resulting in declining wage rates. In such a situation, immigration may cause unemployment among natives who are not willing to work at these lower wages (Boubtane et al., 2013). However, in the presence of complementarity between indigenous and foreign labors, the new inflows of immigrants would augment the productivity of domestic employees and raise their wage levels and employment opportunities (see Borjas, 2001; Boubtane et al., 2013; Feridun, 2004, 2005; Fromentin, 2013). In this respect, the degree of substitutability or complementarity between native and foreign workers determine the final effect of immigration on the domestic labor market.

Relative to the demand-side effects, through their spending on goods and services in a direct way and through industrial and government expenditures on their behalf in an indirect way, immigrants lower the unemployment rate and increase wage levels for the native labors (Islam, 2007). Based on the Say's law in the economic theory, immigrants as consumers demand their own labors (Bodvarsson et al., 2008). In other words, immigration provides a derived demand for labor by contributing to aggregate demand and may not deepen the unemployment problem (Pope \& Withers, 1993).

Because the domestic labor market effect of immigration is difficult to be determined a priori (Islam, 2007), this study aims to analyze whether immigration is a burden or a contribution to the Australian economy over the period of 1966- 
2013. It will also contribute to the related literature in the following ways. First, Australia deserves particular research attention since it is one of the best countries to inhabit by international comparisons of wealth, education, health, and quality of life. Among OECD countries, Australia ranked ninth in respect of foreign population inflow in 2013 (see Fig. 1). It has metropolitan cities such as Melbourne, identified as the world's most liveable city in 2015 with residents from more than 140 nations. ${ }^{1}$ Additionally, the inflow of foreign population into Australia has followed a rising trend, increasing from 69,808 in 1984 to 251,850 in 2013 (see Fig. 2). ${ }^{2}$ The Australian Department of Migration and Border Protection ${ }^{3}$ (2015) reported that Australia's overseas-born population grew by 51.2 percent to 6.4 million people including legal and non-legal immigrants between 1996- 2013. Thus, immigration still continues to be the major component of population growth in Australia. Additionally, approximately 68 percent of Australian immigrants are skilled and educated, and their main birthplaces are mostly developed countries such as the United Kingdom and New Zealand.

\section{Figure 1}

\section{Inflows of foreign population in Australia (1984-2013)}

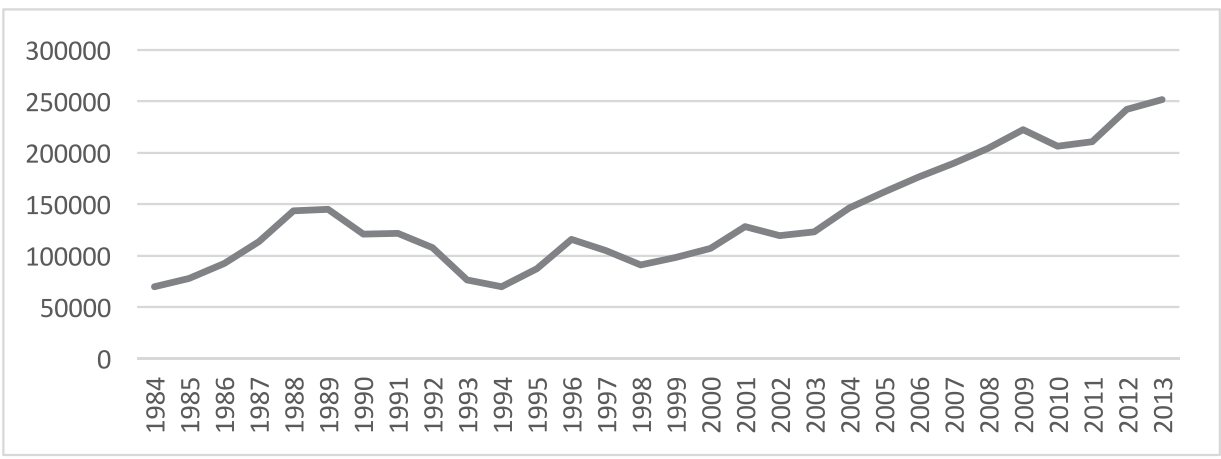

Source: OECD, International migration database.

\footnotetext{
${ }^{1}$ See http://themysteriousworld.com/10-most-liveable-cities-in-the-world/

${ }^{2}$ This number only includes legal immigrants; i.e. people obtaining lawful permanent resident status. See https://www.border. gov.au/about/reports-publications/research-statistics/statistics/live-in-australia/migration-programme

${ }^{3}$ See https://www.border.gov.au/ReportsandPublications/Documents/statistics/migration-trends13-14-glance.pdf ${ }^{2}$ This number only includes legal immigrants;
} 
Figure 2

\section{Inflows of foreign population in 2013 among OEDC countries}

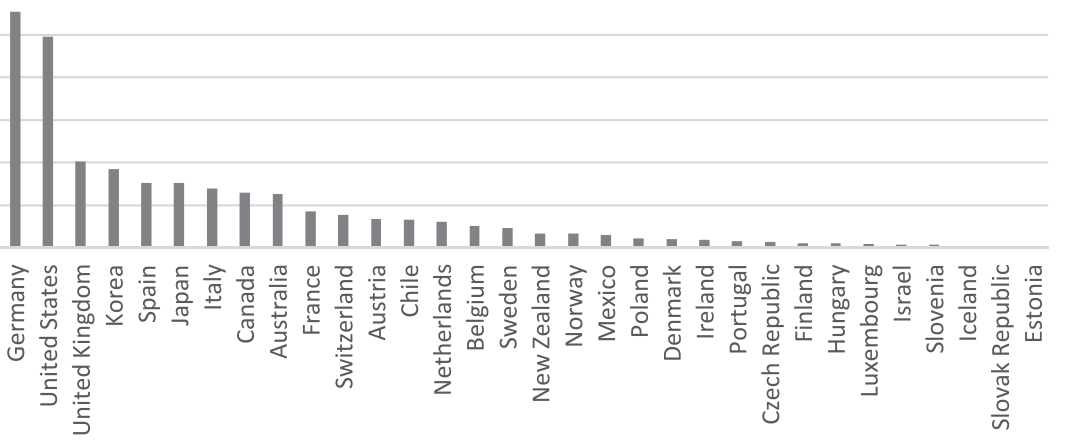

Source: OECD, International migration database.

Second, there are only three empirical studies examining the nexus of immigration and economic conditions for Australia (see Konya, 2000; Pope \& Withers, 1993; Withers \& Pope, 1985). However, this study differs from them by using current data and a novel causality test developed by Hacker and Hatemi-j (2006). This new causality test does not require prior analysis to define the order of integration or co-integration features of the variables. Also, it has more power than other tests in cases of non-normal and autoregressive conditional heteroscedastic error terms and has a bootstrap distribution that is a good approximation for the empirical studies with small samples.

\section{LITERATURE REVIEW}

There are a number of studies attempting to identify the impacts of immigration on the host country's labor market. However, they mostly obtain evidence of causality running from unemployment to immigration instead of from immigration to unemployment (see Feridun, 2007; Islam, 2007; Withers \& Pope, 1985).

The early empirical studies, dating back to the 1980s, applied simple methods such as ordinary least squares (OLS) and/or instrumental variables. For instance, Withers and Pope (1985), using a statistical causality method and a conventional structural model for the years of 1948-1982, found that immigration has no significant impact on unemployment. However, there is a high and meaningful effect running from unemployment to migration for Australia. Pope and Withers 
(1993), using two-stage least squares, supported a bidirectional negative causality between immigration and unemployment in Australia over the period 1861-1991. For Canada, Marr and Siklos (1994), using quarterly data for the period of 19621990 and applying nonparametric multivariate spectral method, indicated that unemployment decreases immigration before 1978, while immigration positively contributed to unemployment after 1978. Pischke and Velling (1997), using OLS for the late 1980s, found no detrimental effect of immigration on native workers' employment in Germany. Dustmann et al. (2005), using data from the British Labor Force Survey and employing the approaches of OLS and instrumental variable for the years 1983-2000, found no substantial evidence that immigration has effects on unemployment and wage levels. Based on a production function and a seemingly unrelated regression approach, Akbari and Devoretz (1992) analyzed the impact of immigrant workers on the employment conditions of Canadian-born workers in 125 Canadian industries for 1980 and suggested no economy-wide displacement of Canadian-born workers by immigrants. By using nonlinear OLS, Dolado et al. (1994) analyzed the effects of migration for 23 OECD countries based on a Solow growth model augmented by migration and human capital over the period of 19601985. Their results indicated that if immigrants have a high level of human capital, their negative output and growth effects diminishes.

There are also recent time series studies applying novel methods. Some of them found that immigration has little or no significant impact on the host country's labor market and economic development level (see Feridun, 2005; Islam, 2007; Shan, 1999). For instance, using quarterly data for the years 1983 to 1995, Shan (1999) found no causality between immigration and unemployment in either direction for Australia and New Zealand in the framework of the causality test of Toda and Yamamoto (1995). Islam (2007) examined the relationship between unemployment and immigration in Canada through cointegration and Granger causality tests for the period of 1961:Q1-2002:Q1. The results confirmed that, in the short-run, there is a one-way negative causality running from unemployment to migration, from migration to wage and from the per capita GDP to migration. However, there is no observed increase in aggregate unemployment rate due to migration in the long- run. The studies by Feridun (2004, 2005, and 2007) investigated the causality between immigration, GDP per capita and unemployment using co-integration and Granger causality tests for Finland (1981-2001), Norway (1983-2003) and Sweden (19802004), respectively. Feridun $(2004,2005)$ obtained evidence that, when the level of immigration goes up, GDP per capita also increases. However, regarding the relationship between unemployment and immigration, Feridun (2004) found that 
rising immigration levels result in a higher unemployment level, whereas Feridun (2005) obtained that immigration has no any impact on unemployment rate, and vice versa. In another study, Feridun (2007) supported a long-run bidirectional causality between immigration and GDP per capita and a one-way causality from unemployment to immigration. For the British Columbia region of Canada, Gross (2004), using the Johansen cointegration test and a vector error correction (VEC) model over the period of 1980:Q1-1995:Q4, found that immigration causes unemployment and raises the real wage in the short-run, while it lowers unemployment in the long-run. In another study, Gross (2002), employing a general equilibrium model, the Johansen cointegration test, and a VEC model, obtained result that show immigrants increase unemployment in the short-run, whereas they lower the unemployment rate in the long-run for the French labor market from 1975 to 1994 . There are also time series studies highlighting that immigration has a beneficial impact on native employment. For instance, Fromentin (2013), using cointegration test and a VEC model over the period of 1970-2008, found evidence of a negative causality running from immigration to unemployment in both the shortand long-run. Konya (2000), through the causality tests proposed by Granger (1969) and Toda and Yamamoto (1995) for 1981:Q2 to 1998:Q4, found a negative causality running from immigration to long-run unemployment rate for Australia.

\section{DATA AND METHODOLOGY}

\section{Data}

We use GDP per capita, unemployment rate, and net migration rate data for the period of 1966- 2013 for Australia. GDP per capita data (constant 2005, US dollar) are collected from the World Bank Development Indicators database. The unemployment rate, measured as the percentage of the total labor force that is unemployed but looking for a job and willing to work, are from the OECD Labor Force Statistics. The net migration rate data, indicating the difference between immigrants and emigrants for a country per 1000 inhabitants, are obtained from OECD International Migration Statistics. All variables are used in their natural

\footnotetext{
${ }^{4}$ See There are also panel data studies (see Angrist \& Krugler, 2003; Basile et al., 2010; Boubtane et al., 2013; Damette \& Fromentin, 2013; Ghatak \& Moore, 2007; Ghatak et al., 2008; Jean \& Jimenez, 2011; Latif, 2015). However, we abstained the detailed explanations for them for the sake of brevity.

${ }^{5}$ We couldn't include wage variable into the analysis due to unavailability of data for the time period of this study. ${ }^{3}$ See https://www.border.gov.au/ReportsandPublications/Documents/statistics/migration-trends13-14-glance.pdf ${ }^{2}$ This number $^{-}$ only includes legal immigrants;

${ }^{6}$ Entries of persons admitted on a temporary basis are not included in this statistic.
} 
logarithmic forms in the analyses, and some statistical features of variables are tabulated in Table 1.

Table 1

Descriptive Statistics of Variables

\begin{tabular}{|l|c|c|c|}
\hline Statistics & InGDP & InUN & InMIG \\
\hline Mean & 25590.10 & 5.973 & 6.531 \\
\hline Median & 24461.31 & 6.090 & 6.141 \\
\hline Maximum & 37494.17 & 10.97 & 14.87 \\
\hline Minimum & 15217.90 & 1.445 & 1.007 \\
\hline Std. Dev. & 6720.868 & 2.599 & 2.774 \\
\hline Skewness & 0.374577 & -0.161 & 0.541 \\
\hline Kurtosis & 1.840232 & 2.385 & 3.416 \\
\hline Jarque-Bera & 3.812584 & 0.965 & 2.691 \\
& $(0.1486)$ & $(0.617)$ & $(0.260)$ \\
\hline
\end{tabular}

Notes: Probabilities were provided in parentheses for the Jarque-Bera test. The null hypothesis for Jarque-Bera test is that the variable has a normal distribution. $\operatorname{lnGDP}, \ln \mathrm{UN}$, and $\ln \mathrm{MIG}$ represent the natural log of per capita GDP, unemployment rate and net migration rate, respectively.

As seen in Table (1), the measures of skewness and kurtosis, as well as the test statistic of Jarque-Berra, support the null hypothesis of a normal distribution for all variables.

\section{METHODOLOGY}

\section{Hacker - Hatemi-J Causality Test (2006)}

The relationship between immigration and economic conditions is extensively analyzed through the Granger causality test in the literature. However, Granger and Newbold (1974) asserted that regression analysis based on the asymptotic distribution theory does not work well, and spurious results can be obtained in the case of non-stationary variables. Also, Sims et al. (1990) indicated that if there are nonstationary variables, the vector autoregressive (VAR) model cannot be used in level form irrespective of the co-integration features of the variables. In such a case, Toda and Yamamoto (1995, TY hereafter) suggested a Wald test statistic that asymptotically has a chi-square distribution irrespective of the order of integration or co-integration features of the variables in the model. TY (1995) proposed the following augmented VAR $p+d$ model: 
(1) $x_{t}=v+A_{1} x_{t-1}+\ldots \ldots \ldots \ldots \ldots \ldots+A_{p+d} x_{t-p-d}+\varepsilon_{t}$

Eq. (1) can be defined in a compact way as follows:

(2) $K=F Z+\psi$

where

$K=\left(x_{1}, \ldots \ldots, x_{T}\right)(n x T)(n x T)$ matrix:

$F=\left(v, A_{1}, \ldots, A_{p}, \ldots ., A_{p+d}\right)(n x(1+n(p+d)))$ matrix,

$Z_{t}=\left[\begin{array}{l}1 \\ x_{t} \\ x_{t-1} \\ \vdots \\ x_{t-p-d+1}\end{array}\right]((1+n(p+d)) x 1)$ matrix, for $t=1, \ldots \ldots \ldots, T$ matrix

$Z=\left(Z_{0}, \ldots \ldots \ldots \ldots, Z_{T-1}\right) \quad((1+n(p+d)) x T)$ matrix

$\psi=\left(\varepsilon_{1}, \ldots \ldots \ldots . . ., \varepsilon_{T}\right)(n x T)$ matrix.

The modified Wald (MWALD) test statistic defined in Eq. (3) is introduced by TY (1995) to test the null hypothesis for non-Granger causality:

(3) $M W A L D=(Y \phi)^{\prime}\left[Y\left(\left(Z^{\prime} Z\right)^{-1} \oplus V_{U}\right) Y^{\prime}\right]^{-1}(Y \phi)$

where $\oplus=$ Kronecker product, $Y=$ ap $\times 1(1+n(p+d)), V_{u}$ is the estimated variance-covariance matrix of residuals in Eq. (2), and $\phi=v e c(F)$, where vec implied the column stacking operator.

The MWALD statistic asymptotically has a $x^{2}$ distribution based on the assumption that error terms are normally distributed, with the number of degrees of freedom equal to the number of restrictions to be tested. TY (1995) asserted that the usage of asymptotical distribution theory is valid in the case of Eq. (2). However, Hacker and Hatemi-J (2006, HH hereafter) proved that MWALD test statistic over rejects the null hypothesis, particularly in cases of non-normal and autoregressive conditional heteroscedastic $(\mathrm{ARCH})$ error terms by utilizing Monte Carlo simulations. They also underlined that asymptotic distribution could be a poor 
approximation for the empirical studies with small samples. HH (2006) indicated that, for the MWALD test, the empirical bootstrap size is close to the correct size in different cases when the extra lags are greater than or equal to the integration order of both variables.

To carry out the bootstrap simulations, Eq. (2) is first estimated with the null hypothesis of Granger non-causality. For each bootstrap simulation, the simulated data is generated, $K^{*}=\widehat{F} Z+\psi^{*}$, where $\widehat{F}$ represents the estimated value of parameters in Eq. (2). The bootstrap $\left(\psi^{*}\right)$ residuals depend on T random draws with replacement from the regression's modified residuals, each with equal probability of $1 / T$. Then, the mean of the resulting set of drawn adjusted residuals is subtracted from each of the modified residuals in that set. The regression's raw residuals are modified to have constant variance through the usage of leverages. The bootstrap simulation is run 100,000 times to compute the bootstrap critical values and the MWALD test statistic is calculated each time. Thereby, the empirical distribution for the MWALD test statistic can be produced.

Before implementing the causality test, we need to determine the maximum integration order $\left(\mathrm{d}_{\max }\right)$ of the variables of interest. For that aim, augmented DickeyFuller (1979, ADF hereafter) and Phillips-Perron (1988, PP hereafter) unit root tests were utilized, and their results were tabulated in Table (2).

Table 2

Augmented Dickey-Fuller and Phillips-Perron Unit Root Test Results

\begin{tabular}{|c|c|c|c|c|}
\hline \multicolumn{5}{|c|}{ Level } \\
\hline & $\begin{array}{l}\text { ADF-Constant- } \\
\text { Trend }\end{array}$ & ADF-Constant & $\begin{array}{l}\text { PP-Constant- } \\
\text { Trend }\end{array}$ & PP-Constant \\
\hline InUN & $\begin{array}{l}-1.4118 \\
(0.8446) \\
\end{array}$ & $\begin{array}{l}-2.0937 \\
(0.2480) \\
\end{array}$ & $\begin{array}{l}-1.4118 \\
(0.8446) \\
\end{array}$ & $\begin{array}{l}-2.0881 \\
(0.2502) \\
\end{array}$ \\
\hline InMIG & $\begin{array}{l}-3.3324^{c} \\
(0.0735)\end{array}$ & $\begin{array}{l}-3.0841^{b} \\
(0.0346)\end{array}$ & $\begin{array}{l}-3.2889^{\circ} \\
(0.0806)\end{array}$ & $\begin{array}{l}-3.0499^{b} \\
(0.0375)\end{array}$ \\
\hline InGDP & $\begin{array}{l}-2.4237 \\
(0.3632)\end{array}$ & $\begin{array}{l}-1.3653 \\
(0.5911)\end{array}$ & $\begin{array}{l}-2.7199 \\
(0.2337)\end{array}$ & $\begin{array}{l}-1.2948 \\
(0.6244)\end{array}$ \\
\hline \multicolumn{5}{|c|}{ First-difference } \\
\hline & $\begin{array}{l}\text { ADF-Constant- } \\
\text { Trend }\end{array}$ & ADF-Constant & $\begin{array}{l}\text { PP-Constant- } \\
\text { Trend }\end{array}$ & PP-Constant \\
\hline InUN & $\begin{array}{l}-6.0625^{a} \\
(0.0000) \\
\end{array}$ & $\begin{array}{l}-5.6996^{a} \\
(0.0000) \\
\end{array}$ & $\begin{array}{l}-6.0683^{a} \\
(0.0000) \\
\end{array}$ & $\begin{array}{l}-5.8002^{\mathrm{a}} \\
(0.0000) \\
\end{array}$ \\
\hline InMIG & $\begin{array}{l}-4.4155^{\mathrm{a}} \\
(0.0055)\end{array}$ & $\begin{array}{l}-4.2870^{\mathrm{a}} \\
(0.0015)\end{array}$ & $\begin{array}{l}-7.5180^{\mathrm{a}} \\
(0.0000)\end{array}$ & $\begin{array}{l}-7.5554^{\mathrm{a}} \\
(0.0000)\end{array}$ \\
\hline
\end{tabular}




\begin{tabular}{|l|l|l|l|l|}
\hline $\operatorname{lnGDP}$ & $-5.6767^{\mathrm{a}}$ & $-5.6996^{\mathrm{a}}$ & $-5.6164^{\mathrm{a}}$ & $-5.6499^{\mathrm{a}}$ \\
& $(0.0001)$ & $(0.0000)$ & $(0.0002)$ & $(0.0002)$ \\
\hline
\end{tabular}

Notes: Probability values are tabulated in parentheses, a, b and c indicate $1 \%, 5 \%$, and $10 \%$ significance levels, respectively. Schwarz information criterion was used in the lag length selection in the ADF test; Bartlett-Kernel as a spectral estimation method and Newey-West Bandwidth as a bandwidth selection method were utilized in the PP test. InUN, lnMIG and lnGDP indicate the natural log of unemployment rate, net migration rate and per capita GDP, respectively.

As reported in Table (2), all variables are stationary in their level or first differences, i.e. they are I (1) or I (0). Therefore, dmax in the TY (1995) and HH (2006) causality tests was decided as one. It is also necessary to define the optimal lag length (p) of the VAR model. Based on the results of Akaike information criterion, three lags were selected as an optimal lag order of VAR model. ${ }^{7}$ Finally, we augmented VAR (3) model with an extra one lag and estimated VAR (4) model. The results of the causality tests are tabulated in Table (3).

As seen in Table (3), the both TY and HH causality tests support the presence of one-way causal relationships running from unemployment to immigration and from GDP per capita to immigration. However, immigration does not appear to have any significant impact on the economic conditions of Australia. As a visual inspection, we also plot immigration with GDP per capita and unemployment and got a negative relationship between unemployment and immigration (see Fig. 3). Therefore, based on Fig. 3 as well as on the causality tests' results, it could be concluded that increasing level of unemployment leads to decreases in immigration inflows. This result is in line with the studies of Feridun (2007), Islam (2007) and Withers and Popp (1985). However, it is in sharp contrast with the studies of Konya (2000), who found a negative causality running from immigration to unemployment, and Pope and Withers (1993), who obtained a bidirectional negative causality between immigration and unemployment.

\footnotetext{
${ }^{7}$ Autocorrelation and heteroscedasticity problems were solved by estimating VAR (3) model.
} 
Table 3

\section{Results of Toda Yamamoto and Hacker and Hatemi-J Causality Tests}

\begin{tabular}{|c|c|c|c|c|c|}
\hline \multirow{2}{*}{ Causualities } & MWALD (TY) & \multirow{2}{*}{ MWALD (HH) } & \multicolumn{3}{|c|}{ Critical Values } \\
\cline { 4 - 6 } & & & $\mathbf{1 \%}$ & $\mathbf{5 \%}$ & $\mathbf{1 0 \%}$ \\
\hline InMIG $\not$ InUN & $\begin{array}{c}2.7621 \\
(0.4298)\end{array}$ & 2.762 & 15.027 & 9.724 & 7.548 \\
\hline InUN $\not$ InMIG & $\begin{array}{c}18.754^{\mathrm{a}} \\
(0.0003)\end{array}$ & $18.753^{\mathrm{a}}$ & 13.735 & 9.000 & 6.977 \\
\hline InMIG $\not A$ InGDP & $\begin{array}{c}3.5765 \\
(0.3110)\end{array}$ & 3.576 & 14.182 & 9.211 & 7.202 \\
\hline InGDP $\not$ InMIG & $\begin{array}{c}10.326^{b} \\
(0.0160)\end{array}$ & $10.326^{b}$ & 13.627 & 8.767 & 6.834 \\
\hline
\end{tabular}

Notes: Probabilities were provided in parentheses; ${ }^{\mathrm{a}}$ and ${ }^{\mathrm{b}}$ indicate $1 \%$ and $5 \%$ significance levels, respectively. Modified Walt test statistics were tabulated for both tests and the critical values for the $\mathrm{HH}$ causality test were provided at $1 \%, 5 \%$, and $10 \%$ significance levels, respectively. TY indicates Toda and Yamamoto (1995) causality test, while HH shows Hacker and Hatemi-J (2006) causality test. lnUN, lnMIG and lnGDP show unemployment rate, net migration rate and per capita GDP, respectively. Critical values were obtained through 100,000 bootstrap replications.

\section{Figure 3}

\section{Plots of immigration with per capita income and unemployment (in logarithmic form)}

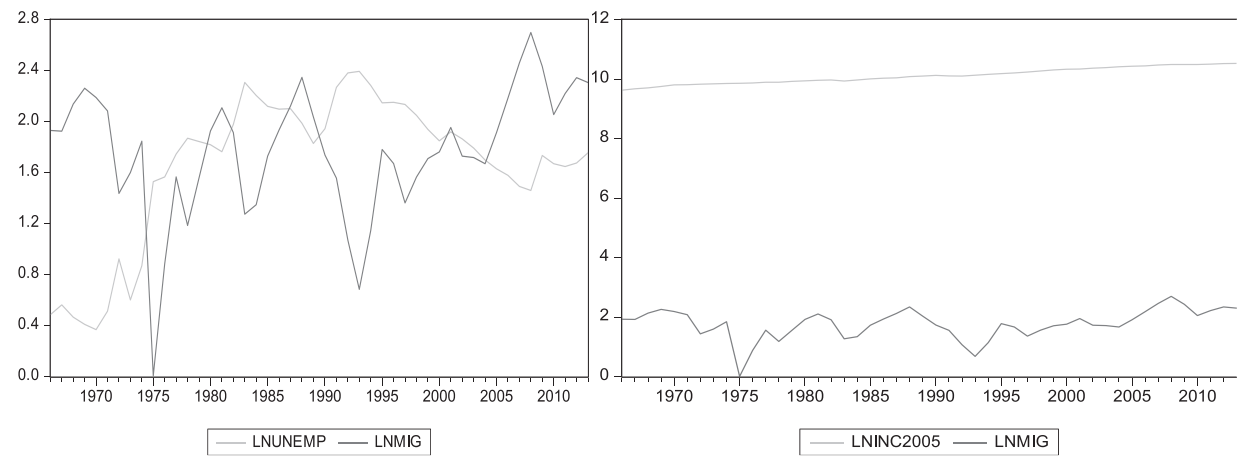

Source: Author's own calculation

However, immigration does not appear to affect the unemployment rate of Australia, probably due to the presence of both substitutability and complementarity among native and immigrant laborers. In this respect, the adverse impacts of substitution on the employment level of Australia appear to be compensated for through the positive effects of complementarity. Additionally, as Gross (2004) asserted, a quality effect may offset the adverse quantity effect from the immigration rate through the high levels of skill and human capital that immigrants have. 
Furthermore, foreign workers accept jobs that are rejected by native workers and fill labor or skill shortages in the host labor markets, which does not lead to an increase in the unemployment rate. Besides, due to the absorptive capacity of the Australian labor market and high-speed adaptation capabilities of immigrant workers, immigration may not aggravate the unemployment level in Australia (Damette \& Fromentin, 2013).

Regarding the relationship between GDP per capita and immigration, there is only a one-way causality running from GDP per capita to immigration. Economic development and a high standard of living are expected to pull more immigrant inflows to Australia. As such, as Latif (2015) states, it is probable that rising GDP per capita provides a signal to potential immigrants about job prospects. However, immigration does not appear to have a significant impact on GDP per capita. This insignificant result implies that the immigrants' human capital levels are high enough to compensate for the adverse effects caused by a reduction in the capital-labor ratio as a result of migration inflow (Boubtane et al., 2013). Our result is similar with those of Islam (2007) and Morley (2006), whereas it is in sharp contrast with Feridun $(2004,2005)$.

\section{CONCLUSION AND POLICY IMPLICATIONS}

In this study, we aim to analyze the relationship between immigration, GDP per capita and unemployment over the period of 1966 - 2013 for Australia by employing the causality tests proposed by Toda and Yamamoto (1995) and Hacker and Hatemi-J (2006). The results provided evidence of one-way causality from both GDP per capita to immigration and from unemployment to immigration. The economic conditions (unemployment level and income level) appear to affect immigration inflows to Australia. In this regard, the low level of unemployment is one of the pulling factors for immigrants into Australia. However, immigration does not have any significant impact on the Australian labor market. This is not an odd result because as Boubtane et al. (2013) state, the empirical studies mostly conclude that immigration does not reduce the labor market prospects of natives. Concerning the relationship between GDP per capita and immigration, the results indicate only a one-way causal relationship from GDP per capita to immigration. As such, the higher per capita income level Australia has, the more people immigrate to Australia. However, immigrants do not appear to affect the income per capita level of Australia.

Overall, our results revealed that immigration inflows do not harm the employment prospects of Australian residents. As a policy implication, the Australian 
government does not need to arrange restrictive immigration policies to prevent new immigrant inflows because they are not harmful to the domestic labor market. As stated before, Australian immigrants have a high level of human capital, and thus they should not be seen as threats to the Australian economy. Moreover, through new integration policies, immigrants could quickly adjust to their new life conditions, and their non-significant employment and income effects would be turned into significant and positive ones.

\section{REFERENCES}

Akbari, A. H., \& Devoretz, D. J. (1992). The substitutability of foreign-born labor in Canadian-production: circa 1980. The Canadian Journal of Economics, 25, 604-614.

Angrist, J. D., \& Kugler, A. D. (2003). Protective or counter-productive? Labor market institutions and the effect of immigration on EU natives. The Economic Journal, 113, 302-331.

Aydemir, A., \& Borjas, G. J. (2006). Comparative analysis of the labor market impact of international migration: Canada, Mexico, and the United States. (NBER Working Paper No. 12327). Cambridge, MA: National Bureau of Economic Research.

Australian Department of Immigration and Border Protection. (2015) Australia's Migration Trends 2013-14 at a glance. Retrieved from https://www.border. gov.au/ReportsandPublications/Documents/statistics/migration-trends13-14glance.pdf

Basile, R., Girardi, A. \& Mantuano, M. (2012). Migration and regional unemployment in Italy. The Open Urban Studies Journal, 5, 1-13.

Bodvarsson, O. B., Berg, H. F. V. \& Lewer, J. J. (2008). Measuring immigration's effects on labor demand: A reexamination of the Mariel Boatlift. Labor Economics, 15, 560-574.

Borjas, G. J. (2001). Does immigration grease the wheels of the labor market? Brookings Papers on Economic Activity, 1, 69-119.

Borjas, G. J. (1994). The economics of immigration. Journal of Economic Literature, XXXII, 1667-1717.

Boubtane, E., Coulibaly, D. \& Rault, C. (2013). Immigration, unemployment and GDP in the host country: Bootstrap panel Granger causality analysis on OECD countries. Economic Modelling, 33, 261-269. 
Damette, O., \& Fromentin, V. (2013). Migration and labor markets in OECD countries: a panel cointegration approach. Applied Economics, 45, 2295-2304.

Dickey, D.A., \& Fuller, W.A. (1979). Distribution of the estimators for autoregressive time series with a unit root. Journal of the American Statistical Association, 74, 427-431.

Dolado, J., Goria, A., \& Ichino, A. (1994). Immigration, human capital and growth in the host country. Journal of Population Economics, 7, 193-215.

Dustmann, C., Fabbri, F., \& Preston, I. (2005). The impact of immigration on the British labor market. The Economic Journal, 115, 324-341.

Feridun, M. (2007). Immigration, income and unemployment: an application of the bounds testing approach to cointegration. The Journal of Developing Areas, 41, 37-49.

Feridun, M. (2005). Investigating the economic impact of immigration on the host country: The case of Norway. Prague Economic Papers, 4, 350-362.

Feridun, M. (2004). Does immigration have an impact on economic development and unemployment? Empirical evidence from Finland (1981-2001). International Journal of Applied Econometrics and Quantitative Studies, 1, 39-60.

Fromentin, V. (2013). The relationship between immigration and unemployment: The case of France. Economic Analysis \& Policy, 43, 51-66.

Ghatak, S., Mulhern, A., \& Watson, J. (2008). Inter-regional migration in transition economies: The case of Poland. Review of Development Economics 12, 209222.

Ghatak, S., \& Moore, T. (2007). Migration and the EU labor market: Granger causality tests on a panel VAR. (Discussion Paper). Kingston upon Thames, U.K.: Faculty of Arts and Social Sciences, Kingston University

Granger, C. W. J. (1969). Investigating causal relations by econometric models and cross-spectral methods. Econometrica, 37, 424-438.

Granger, C. W. J. \& Newbold, P. (1974). Spurious regression in econometrics. Journal of Econometrics, 2, 111-120.

Gross, D. M. (2004). Impact of immigrant workers on a regional labor market. Applied Economic Letters, 11, 405-408.

Gross, D. M. (2002). Three million foreigners three million unemployed? Immigration flows and the labor market in France. Applied Economics, 34, 1969-83.

Hacker, R. S. \& Hatemi-J, A. (2006). Tests for causality between integrated variables using asymptotic and bootstrap distributions: theory and application. Applied Economics, 38, 1489-1500. 
Islam, A. (2007). Immigration unemployment relationship the evidence from Canada. Australian Economic Papers, 46, 52-66.

Jean, S., \& Jiménez, M. (2011). The unemployment impact of immigration in OECD countries. European Journal of Political Economy, 27, 241-256.

Konya, L. (2000). Bivariate causality between immigration and long-term unemployment in Australia, 1981-1998. (Working Paper No. 18). Melbourne, Australia: Victoria University Applied Economics.

Latif, E. (2015). The relationship between immigration and unemployment: Panel data evidence from Canada. Economic Modelling, 50, 162-167

Marr, W. L., \& Siklos, P. L. (1994). The link between immigration and unemployment in Canada. Journal of Policy Modeling, 16, 1-26.

Morley, B. (2006). Causality between economic growth and immigration: An ARDL bounds testing approach. Economics Letters, 90, 72-76.

OECD. (2016). International migration database. Retrieved from

https://stats.oecd.org/Index.aspx? DataSetCode $=M I G$

OECD. (2016). Labor Force Statistics. Retrieved from http://www.oecd.org/ employment/labour-stats

Peri, G. (2008). Immigration accounting: U.S. States 1960-2006. (Discussion Paper Series No: 05). London: Centre for Research and Analysis of Migration.

Phillips, P. C. B. \& Perron, P. (1988). Testing for a unit root in time series regression. Biometrika, 75(2), 335-346

Pischke, J. S., \& Velling, J. (1997). Employment effects of immigration to Germany: An analysis based on local labor markets. The Review of Economics and Statistics, 79, 594-604.

Pope, D., \& Withers, G. (1993). Do migrants rob jobs? Lessons of Australian history, 1861-1991. The Journal of Economic History, 53, 719-42.

Shan, J. (1999). Immigration and unemployment: New evidence from Australia and New Zealand. International Review of Applied Economics, 13, 253-260.

Sims, C. A., Stock, J. H., \& Watson, M. W. (1990) Inference in linear time series models with some unit roots. Econometrica, 58, 133-144.

Toda, H. Y., \& Yamamoto, T. (1995). Statistical inference in vector auto regressions with possibly integrated processes. Journal of Econometrics, 66, 225-250.

Troshchenkov, S. (2011). Influence of immigration on the unemployment rate: The case of Denmark. (Master's Thesis, Umea University, Sweden). Retrieved from https://www.diva-portal.org/smash/get/diva2:523614/FULLTEXT01.pdf

Withers, G. \& Pope, D. (1985). Immigration and unemployment. Economic Record 61, 554-563. 
World Bank. (2016). Development Indicators Database. Retrieved from http://databank.worldbank.org/data/reports.aspx?source=world-developmentindicators

\section{BRIEF BIOGRAPHICAL SKETCH OF AUTHOR}

Dr. Burcu Ozcan got her $\mathrm{PhD}$ degree in Economics from Istanbul University in 2011. She is now an associate professor of Economics in the Faculty of Economics and Administrative Sciences at Firat University in Turkey. She teaches macroeconomics and monetary economics. Her primary research areas are energy economics, information economics and development economics. She was a visiting professor in the Business Administration College at Sam Houston State University from April through September, 2016. 